\title{
Perception of Money Politics, Hoax and Sara Issues in 2019 Elections
}

\author{
Syamsul Umam \\ Institut Agama Islam Negeri Tulungagung, Indonesia \\ samsulumam80@gmail.com
}

\begin{abstract}
Research on students' perceptions about money politics, hoaxes and sara issues in the 2019 elections in Tulungagung Regency is motivated by the high practice of money politics in various political events, from local elections to elections, on the basis that researchers try to photograph how students' understanding of money politics, hoaxes and the issue of sara, this study uses a qualitative method that is collecting data obtained from the results of interpretation in the field, this study also portrays the implications of money politics, hoaxes, sara issues to influence the choice of students in Tulungagung Regency in the 2019 Election, it is seen from the results Researcher's interviews with a number of informants resulted in students' understanding of money politics, hoaxes and sara issues being very good, students understanding the understanding of money politics in detail, even when in the construction of student money politics understanding in Tulungagung Regency almost approached the existing understanding in the law of the government. You do not stop their students also understand various phenomena of money politics and their modes, students' understanding of hoaxes with content issues is also quite good because almost all students define hoax details with examples and models of their stories, students also assume that spreading the issue of care in the general election contestation is considered to be very dangerous and for the continuation of democratic life in Indonesia which causes divisions and disintegration.
\end{abstract}

\section{Keywords: Money Politics, Hoax, Sara Issues, Students in Tulungagung}

\begin{abstract}
Abstrak
Penelitian mengenai persepsi pelajar tentang politik uang, hoax dan isu sara pada pemilu 2019 di Kabupaten Tulungagung dilatarbelakangi dengan tinggi nya praktek politik uang dalam berbagai event politik, mulai pilkada hingga pemilu, atas dasar tersebut peneliti mencoba untuk memotret bagaimana pemahaman pelajar terhadap politik uang, hoax dan isu sara, penelitian ini menggunakan metode kualitatif yaitu mengumpulkan data-data yang diperoleh dari hasil interpetasi dilapangan, penelitian ini juga memotret implikasi politik uang, hoax, isu sara untuk mempengaruhi pilihan kaum pelajar di Kabupaten Tulungagung pada Pemilu 2019. Hal tersebut terlihat dari hasil wawancara peneliti dengan sejumlah informan hasilnya pemahaman pelajar terhadap politik uang, hoax dan isu sara sangat bagus, para pelajar memahami pengertian politik uang secara detail, bahkan kalua di konstruksi pemahaman politik uang kaum pelajar di Kabupaten Tulungagung hampir mendekati pengertian yang ada dalam undangundang pemilu, tidak sampai disitu para pelajar juga memahami berbagai fenomena politik uang beserta modus-modusnya, pemahaman pelajar terhadap hoax dengan konten isu sara juga cukup baik, karena hamipr sebagian besar pelajar mendefinisikan hoax detail dengan contoh-contoh beserta model
\end{abstract}


beritanya, para pelajar juga menganggap bahwa penyebaran isu sara dalam kontestasi pemilihan umum dianggap sangat berbahaya dan bagi keberlangsungan kehidupan demokrasi di Indonesia yang menyebabkan perpecahan dan disintegrasi.

Kata Kunci: Politik Uang, Hoaks, Isu Sara, Pelajar Tulungagung

\section{Introduction}

Elections are a five-year celebration of democracy that is based on the principle of the General Direct Free Honest and Fair (LUBERJUDIL) and based on the Pancasila and the 1945 Constitution of the Republic of Indonesia. Through general elections, a government whose policies are impartial to the people can be replaced through an election mechanism. re-elect it in the next election as a form of correction and accountability. That way democracy directly tries to realize a clean government chosen by the people to improve people's welfare.

Related to the implementation of the 2019 election, the awareness of new voters has a very significant influence in voting for the 2019 election, because the awareness of new voter voters will have an impact on whether or not the government system will affect the life of the nation and state. Based on data obtained from the Permanent Voter List in Tulungagung Regency which amounted to 852,874 voters with details of 424,007 male voters and 428,797 female voters, while the number of disability voters was 1,684 voters and 11,519 first-time voters and spread out in 19 districts and 271 villages in Tulungagung Regency. ${ }^{1}$ The number of voters in this study has an important role in influencing the vote acquisition for a particular candidate. Based on East Java BPS data the number of students in Tulungagung Regency is 13,363 students, ${ }^{2}$ while students who take UNBK are 9,654 students meaning that there are around 80 percent more beginner voters in Tulungagung Regency the number of voters above will be useless if the population is not involved or apathetic towards the 2019 election.

As a novice voter as well as the next generation of the nation, students have a very important contribution in organizing elections, unfortunately novice voters respond less or respond to information relating to politics. Based on preliminary studies that

${ }^{1}$ Based on the Decree of the Tulungagung Regency KPU Number : 87/PK.01-BA/02/KPUKab/IV/2019 Concerning Recapitulation Plenary Meeting and Determination of the Final Voters Register Result of Improvement to the three levels of Tulungagung Regency in the 2019 General Elections

${ }^{2}$ East Java BPS data on the number of High School Students in Tulungagung Regency can be accessed via the link https://jatim.bps.go.id/dynamictable/2017/09/22/104/jumlah-sekolah-murid-gurudan-rasio-murid-guru-sekolah-menengah-atas-sma-menurut-kabupaten-kota-di-provinsi-jawa-timur2017.html

Tribakti: Jurnal Pemikiran Keislaman Volume 31, Nomor 2, Juli 2020 
researchers have done, it is obtained data that the average student or novice voter responds less to information relating to politics, both information conveyed by print media and electronic media, on average students assume information about politics, especially elections, is considered not too important and interesting, they only assess the figure of a good leader in terms of physical without knowing the competencies of the prospective leader, not only that some beginner voters are apathetic and they think that choosing or not choosing a particular leader they feel remains the same ie no changes will occur. Novice voters are very easily influenced to engage in political activities without realizing that they do not know the essential politics themselves. Beginner voter students are very interesting to study because they are one of the mass bases targeted by political parties to gather political votes.

On the other hand, the face of democracy is immediately tarnished by the outbreak of money politics in the five-year political arena. A candidate who is supposed to represent his capacity and concern to the community, on the contrary makes the process of the relationship between the two to be pragmatic transactional. By all means and various modes available, the game of money politics is difficult to be sniffed by the rules. Even the community itself is permissive as if it has become something that is normal and is considered as "compensation" in political communication that runs poorly between political parties, candidates, and the community.

Money politics itself can be defined as a form of giving money (material) or a person's promise to others so that the person does not exercise his rights as a voter or so that the person chooses him in the TPS booth. ${ }^{3}$ The form of giving can also be done by using money or goods with the aim that the public is interested and sympathetic towards a particular candidate or party, money politics itself is not merely a matter of material, there is also assistance in the form of program activities or other populist programs.

As stated by Abdus Salam, money is sometshing that fascinates the people especially related to the democratic party, the people do not understand the nature of money politics practices for the sustainability of democracy, while for some candidates in the democratic contestation the practice of money politics is one of the most effective campaign strategies effective in building sympathetic communities. ${ }^{4}$ The same opinion was also said by Emerson Yuntho that the practice of money politics occurred in the

${ }^{3}$ Ibrahim Zuhdhy Papers, Money and Pilkada (Jakarta : Indonesia Corruption Watch, Januari

${ }^{4}$ Abdu Salam, Politik, "Uang dan Pilkada", Papers 09 Juni 2010 
elections and the election began from the determination of the name of the candidate to voters using their political rights in the voting booths (TPS). The practices and patterns of money politics are almost the same as in previous years, namely by providing food packages, providing transportation money during the campaign, as well as providing food allowance at limited meetings held by candidates and political parties during the campaign.

Interestingly, in the implementation of the 2018 elections and 2014 legislative elections in Tulungagung Regency, Panwaslu in its report submitted to East Java Bawaslu did not record any violations in the form of money politics. The things that Panwaslu reported most were related to administrative violations such as the installation of campaign attributes, the use of public facilities, the clash between supporters of candidates / pairs of candidates, and violations of the time and place of the campaign. Apart from the difficulty of the money politics case, it was addressed by the existing rules, this issue has come to the attention of many parties both academics, political observers, organizers and supervisors of the election itself, that money politics endanger and conflicts with democracy.

In addition to money politics, democracy is now also faced with the problem of hoaxes or false news which is an interesting phenomenon in the modern political world in Indonesia. According to Septiaji Nugroho. ${ }^{5}$ In the digital era democracy many cloned / fake accounts that appear and spread in various social media such as Twitter, YouTube, Facebook, and others. The account spreads the issue of SARA, slander, and even black campaigns against certain candidates, the phenomenon is increasingly finding its momentum approaching the election succession. Even from survey data released by Mastel Indonesia, $44.30 \%$ of people receive hoax news content every day, while almost $62.10 \%$ of them receive hoaxes or hoaxes in written form and as much as $92.40 \%$ of people receive hoax news These are shared from social media. ${ }^{6}$

The hoax will certainly worsen the image of democracy in Indonesia, even at some point it has seriously damaged the social harmony of society and the democratic order of values in the country. Indeed social media which is a value-free technology product has

5 Septiaji Nugroho, “Cara Cerdas Mencegah Penyebaran Hoax di Media Sosial,” Kompas.com, 22 November 2017, https://nasional.kompas.com/read/2017/11/22/08020091-cara-cerdas-mencegahpenyebaran-hoax-di-media-sosia.

6 "Infografis Hasil Survey MASTEL Tentang Wabah HOAX Nasional | Mastel.Id," MASTEL (blog), 13 Februari 2017, http://mastel.id/infografis-hasil-survey-mastel-tentang-wabah-hoax-nasional/. Tribakti: Jurnal Pemikiran Keislaman Volume 31, Nomor 2, Juli 2020 
a double face in democracy, that is, on one side social media is used as the oxygen of democracy, on the other hand, social media can be used to "kill" democracy itself.

From the facts as outlined by the researchers, several fundamental questions arise whether the internet will be a friend or foe for democracy? To answer these questions there are three 3 (three) approaches that researchers try to express First; the pessimistic approach, the Second, the optimistic and Third approach; the realistic approach. The first approach; do not believe that social media can be a loyal friend of democracy, they assume that social media on the contrary stabs from behind the ongoing democracy. While the second approach; believes that social media can be friends and strengthen modern democracy both at the global and local levels. Next according to the third approach; said that social media can stand in balance between the two extreme points that exist and be able to push the democratic side of social media itself while continuing to recognize and minimize its anti-democratic aspects. ${ }^{7}$

\section{Methode}

This study uses a qualitative method. Bogdan and Taylor define qualitative methodology as a research procedure that produces descriptive data in the form of written or spoken words from people and observable behavior. The approach is directed towards the background and the whole individual. Nasution also emphasized that the qualitative approach was essentially observing people in their environment, integrating with them trying to understand their language and interpretation of the world around them. To obtain data researchers went to the field by conducting in-depth observations and interviews on the activities of the subjects studied.

In this study, people will be observed, namely students in several Vocational High Schools (SMA) Vocational School or novice voters in elections registered in the Permanent Voter List (DPT) Tulungagung Regency. Students who have registered with the DPT have the right to vote and can be used to elect people's representatives (DPR-RI, Provincial DPR, and City Regency DPRD) and the President and Vice-President in the 2019 Election. With a qualitative approach, the data obtained will be more complete, more in-depth, more credible, and more meaningful so that research objectives can be achieved. By using a qualitative approach a broad and in-depth description of behaviors,

${ }^{7}$ Anthony G. Wilhelm, Demokrasi di Era Digital : Tantangan Kehidupan Politik di Ruang Cyber (Yogyakarta: Pustaka Pelajar, 2003). Hlm. 67 
mental attitudes, feelings, and beliefs held by a person or group in the environment can be found. ${ }^{8}$

In that context too, this type of research is a case study in which a researcher tries to explore data specifically for an event or event that has its characteristics or uniqueness on an object being studied. ${ }^{9}$ Of course in this study are the characteristics of cases in the 2019 general election.

While the type of research conducted is descriptive. Where according to Erna Widodo, a descriptive research method is a method used to find the broadest possible knowledge of the object of research at any given moment. This research will try to describe the facts relating to money politics, hoaxes, and Sara issues during the elections in Kediri and Tulungagung Regency, such as the activities and behavior of the candidates and the successful team in their constituencies. As well as providing possibilities for changes when more basic and interesting facts are found in the field. The facts obtained will be linked to the research objectives.

\section{Results and Discussion}

How Students' understanding money politics, hoaxes and Sara issues in the 2019 elections

Money politics, hoaxes, and Sara issues seem to have become a phenomenon that is so plural in various layers and social groups in Tulungagung Regency. Even the views on the spread of money politics, hoaxes and Sara issues as stated by AAZ students (18 Years) SMAN 1 Kedungwaru Tulungagung that "Money politics is carried out by someone who will be elected using money to buy voting rights from such simple voters" 10

From the results of interviews with students, data was obtained that money politics became common and natural. As also stated by a student named MZR (18 years) regarding the issue of money politics said that money politics has become a public secret in society. Not only the general election, according to this high school student, from the smallest things like the election of the Head of the RT alone does not escape the target of people who are interested in occupying certain positions through money politics strategies. According to blame is easily coordinated voter behavior through bribery.

${ }^{8}$ Suharsimi Arikunto, Prosedur Penelitian: Suatu Pendekatan Praktek. (Jakarta: PT. Rineka Cipta), 2002, hlm. 29.

9 Sugiyono. Metode Penelitian Administrasi. (Bandung: CV. Alfabeta), 2004, hlm. 88.

${ }^{10}$ Results of Interview with Informan on 15 Juni 2019

Tribakti: Jurnal Pemikiran Keislaman

Volume 31, Nomor 2, Juli 2020 
"The thing is that money politics is frankly known to everyone, we don't have to go far, we take the example of village head elections, if we don't use politeness, we might not be supported. That's something normal. I just mean stupid voters. Because it can be bribed. We should look at figures, how the background of the candidate, his education. So actually, education is not good enough in my opinion. But that is normal ". ${ }^{11}$

In addition to the issue of money politics, the writer further asks students' understanding of hoax related to SL students (18 years), he thinks that Yahax is inaccurate news and does not meet journalistic methods; "Hoax is untrue hoaxes. Intentionally spread through social media, and various other media, which aims to influence readers, to believe in an event, and the news is considered accurate and true ". ${ }^{12}$

From some of the students' opinions, it appears that they understand the hoax in the form of memes and narratives that fill the social media space, most of the hoax's content contains describing a particular candidate or delegitimizing the process of holding ongoing general elections. Students also understand that hoaxes are views and actions based on identity sentiments concerning heredity, religion, nationality or ethnicity and certain groups. "The issue of sara is something that is related to ethnicity, race, or religion, it may further corner one religion". ${ }^{13}$

From the above interview results, the author concludes that most students in Tulungagung Regency understand very well that giving cash or goods with the lure of promises to choose themselves is categorized and considered as money politics, this is in accordance with the definition of money politics according to the Act Law, while Tulungagung Regency students understand hoax news very well, according to the understanding of most students of hoax news is unclear news, a small number of students in Tulungagung District also understand that hoax is a diversion of issues carried out by the government because it is considered a failure in fulfilling his promise.

\section{Factors that influence students' perceptions of money politics, hoaxes, sara issues}

\section{Regulatory Factors}

Regulation becomes one of the factors that influence perception because in the design of election law enforcement, criminal and administrative sanctions can be a strategic step in preventing and cracking down on the practices of money politics, hoaxes

\footnotetext{
${ }^{11}$ Results of Interview with Informan on 16 Juni 2019

${ }^{12}$ Results of Interview with Informan on 16 Juni 2019

${ }^{13}$ Results of Interview with Informan on 16 Juni 2019
} 
and the spread of sara issues. As stated by Musthofa, the Chairperson of the Tulungagung District Election Commission stated as follows:

"Defining money politics refers to existing regulations or laws. The law governing the election itself and the Pilkada itself so that Bawaslu can not take action against money politics. Before I was in the KPU I had the background of the election supervisor even yesterday who handled the handling of money politics, and I know exactly how, so we cannot take action if it is formally and materially unproven. Money politicians give or receive evidence or there is an impact on the gift. Apart from that, more than that a description of the event there are actors and recipients and impact. If it is just giving and there is no impact, even then in the election law or Law 7 of 2017 Yesterday it was also difficult to enter the realm of money politics. Including the differences between the electoral law and yesterday's election law, one of which became the object of the difference for the referenced election in Law 10 of 2016 while the election of Law 7 of 2017 one of the most important differences relating to money politics". 14

Regulation in this context is the Election Law as a criminal law, so we must discuss 3 important parts in criminal law, first is a criminal act, the criminal act in an election is regulated in Book $\mathrm{V}$ under the election criminal section stated in articles 488 to 554, in the book consists of 66 election criminal acts, the election criminal act itself is divided into several categories, the first category of criminal acts committed by organizing elections as background in articles 489, 499, articles 501-508, articles 513, 514, 518, 524, 537-539 as well as articles 541-546 and 551. Both election criminal offenses committed by the general public are regulated in 22 articles, namely Article 488, 491, Articles 497 498, Article 500, Article 504, Article 509-511, Article 515- 517, Article 519-520, Article 531-536, Article 544, Article 548. Third, election criminal acts by the government apparatus, stipulated in 2 articles namely Article 490 and 494. Third, election criminal acts committed by the organizer state or public official, stipulated in 2 articles namely Article 522 and 547. Fourth, election criminal offenses committed by corporations, regulated in 5 articles include: Article Article 498, Article 525 paragraph (1), Article 526 paragraph (1), Article 529-530. Fifth, election criminal acts carried out by campaign organizers and election participants consist of 9 articles namely Article 495, 496, Article 521, Article 523, Article 525 paragraph (2) Article 526 paragraph (2), Article 527 and Article 528, Article 550 Election criminal acts by presidential and vice presidential candidates, consisting of 2 articles namely Article 552 and Article 553 Specifically regarding the crime of money politics, regulated in Article 523 paragraph (1) expressly

${ }^{14}$ Results of Interview with Informan on 5 July 2019

Tribakti: Jurnal Pemikiran Keislaman

Volume 31, Nomor 2, Juli 2020 
threatens those who promise money to voters with a sentence of two years in prison and a material fine of Rp. 24 million. If the gift of money or goods is carried out during a quiet period the sentence is four years in prison and a fine of Rp. 48 million. Severe sanctions are given if giving money or goods carried out on D-Day is threatened with a sentence of three years in prison and a fine of Rp. 36 million.

But the discourse that was held, there were no firm conclusions about money politics. There are no clear boundaries between the practice of buying and selling votes and spending money from parties for concrete purposes. The demarcation line between money politics and political financing is still very blurred. Even so it does not mean that no one has tried to define the term money politics. One of them, money politics is usually interpreted as an effort to influence people's behavior by using certain rewards. There are also those who interpret money politics as an act of buying and selling votes in a political process and power. These actions can occur in a wide range, from village head elections to general elections in a country. ${ }^{15}$

In addition to the Criminal Acts for money politics, regulations regarding hoax spreaders have also been regulated in Law Number 10 of 2016 in article 69 which clearly states prohibitions in campaigns such as inciting, slandering, pitting political parties, individuals and or community groups. This article should still be relevant to be used to crack down on the spread of hoaxes on social media, besides that the spread of hoaxes can also be snared with Law Number 19 of 2016 concerning Information and Electronic Transactions (ITE) article 28. But law enforcement is not done seriously for disseminators hoaxes on social media as in conventional media such as props and campaign materials so as to make room for candidates to carry out black campaigns and even spread hoax.

\section{Open proportional system factors in the 2019 elections}

The design of the electoral system in 2019 uses open proportionality, the electoral system becomes one of the factors of the rise of political money in the 2019 elections, by using an open proportional system competition between candidates is tighter in one electoral district, because campaign and party victory are entirely in the hands of each

15 Ismawan, I. Money Politics Pengaruh Uang dalam Pemilu (Yogyakarta: Media Pressindo, 1999), Hlm. 5. Agustino, L. Pilkada dan Dinamika Politik Lokal (Yogyakarta: Pustaka Pelajar, 2009), Hlm.22. 
candidate to get the most votes his fellow party candidates were represented by him. As conveyed by Adib Makarim the Chairperson of DPC PKB Tulungagung as follows:

"Because the 2019 election model uses an open proportional system, the competition in each electoral area is getting tougher, competition does not only occur between parties, but also fellow legislative candidates, so that candidates try to find the most votes in their electoral districts, of course various methods are carried out to attract the voters so they can vote for it". ${ }^{16}$

An open proportional system is one factor in the increasing practice of money politics. If we look at it since the first election after the reformation, money politics almost did not occur because the election at that time was still using a closed proportional system that only casted political party signs. The practice of money politics began to flare up since the 2009 elections because it used an open proportional system. ${ }^{17}$ This tendency can be proven in every election implementation, where political parties have started earlier by transacting to sit in party management, continued in the determination of the calendars, and to win the battle of candidates to carry out political transactions with voters.

In a study of political clientelism, in terms of perverse accountability, the voters should be able to hold politicians accountable for realizing their political promises because they have given their votes, but instead politicians dictate voters to vote because they have received something from the candidate.

In addition to money politics, candidates who do not have a vision will launch a black campaign to bring down political opponents, this can be seen from the development of hoaxes and hate speech during the 2019 election campaign period. Campaign media should be used by candidates to close public space with more positive information, compared to negative narratives. these candidates can actively participate using public space to campaign, conveying their vision and mission and programs. There are many spaces and mechanisms that candidates can use for campaigns. Starting from the use of banners, billboards, intensive limited meetings, the use of social media that is open to the public should be optimal as an initial introduction to the profile of the candidates in conveying their vision and mission; before entering the campaign form.

But it is unfortunate, the campaign space that has been opened wide is not used to its full potential to convey ideas to voters widely. But the candidates like to choose shortcuts by using the politics of splitting bamboo, stepping on opponents through hoax

\footnotetext{
${ }^{16}$ Results of Interview with Informan on 8 July 2019

${ }^{17}$ Burhanuddin Muhtadi, Politik Uang dan New Normal dalam Pemilu Paska Orde Baru, Jurnal Antikorupsi INTEGRITAS, 5 (1), 55-74
}

Tribakti: Jurnal Pemikiran Keislaman

Volume 31, Nomor 2, Juli 2020 
news. So that popular and viral terms emerge but don't educate let alone be informative. So the news that appears cannot be used at all as a consideration for selecting candidates.

\section{Election Ability Capability Factor}

According to Ramlan Surbakti (2014), the assessment indicators on election integrity do not only focus on the professionalism of the organizers, but also highlight the behavior of competitors. This is intended so that the ongoing competition does not harm the principle of electoral justice. In this context, electoral justice can be interpreted, as explained by the Institute for Democracy and Electoral Assistance (IDEA), as respect for the rule of law, human rights, and dispute resolution according to applicable legal procedures. ${ }^{18}$ As said by Dr. Dian Ferrica, MH, one of the East Java Regional Election Commission 5 member selection team said "The selection team of KPU members works based on the mandate of existing laws and regulations, so that the selection team can produce members of the KPU commissioners with integrity in the process of organizing elections". 19

As in article 28 of KPU Regulation Number 1 of 2018 concerning Guidelines for the Implementation of Selection and Determination of Provincial KPU and Regency / City KPU Members, the eligibility test for a person to become a KPU member includes (a). integrity and independence, (b). knowledge of electoral, (c). nationality insight, (d) leadership, (e) communication skills and (f) clarification of community responses.

The points in PKPU are certainly ideal in finding capable and integrity election administrators, but the facts about someone's integrity need to be tested through the person's track record so far, so it is clear how the integrity and experience of the election organizers is. In addition, the quality of an organizer also becomes important, because it concerns how the electoral process can work well, especially in dealing with the problem of the final voter list until the determination of candidates is often disputed by candidates.

In addition to the KPU-PPK and PPS, organizers such as Bawaslu also become one of the success factors in organizing elections, as stipulated in Law Number 7 of 2017, bawaslu has the authority to accept and follow up complaints about election violations, examine and review violations both administrative and political money, bawaslu also has

${ }^{18}$ Ferhadz Ammar Muhammad, Menyikapi Isu Kecurangan Pemilu, Artikel yang dimuat dalam Detik.com pada tanggal 15 April 2019 dapat diakses melalui link https://news.detik.com/kolom/d4511134/menyikapi-isu-kecurangan-pemilu

${ }^{19}$ Results of Interview with Informan on 8 July 2019 
the authority to recommend criminal violations to the police. So that enforcement of election violations can be strictly carried out if the organizer has high capability and integrity, because enforcement of violations is the key to the successful implementation of direct, free, honest, fair elections, especially related to classic issues in elections such as money politics and campaigns black (hoax).

\section{Implications of money politics, hoax news dissemination and sara issues}

\section{Unstable political climate}

As revealed by the Office of Democracy and Governance (2003), there are 4 types of potential risks in money politics. First is the "uneven playing field". In this context, money has an impact on unhealthy competition between one group and another ${ }^{20}$ This has an impact on competition between candidates in an unequal electoral district, so candidates who have capital money can master the game. Second is "unequal access to the office". It is intended that money will create discrimination against the politics of representation. Because the political process is only monopolized by candidates who have money. The Third is "co-opted politicians" meaning that money can create an unbalanced pattern of relations, candidates can dictate voters because voters get rewards from candidates, so the election process no longer meets the principles of honestly and fairness. The fourth is "tainted politics" money will give birth to the power that tends to corrupt, because the election process is dominated by money, the elected candidates tend to think of returning the capital that has been issued. As said by Muhammad Zainal Rizal Student of SMAN 1 Kedungwaru Tulungagung Regency as follows:

"With money politics, the political system in the country has become unstable, in the five-year elections the leader may change even though the incumbent candidate is good at governing, but because he has no money he is not reelected for the next five years". ${ }^{21}$

Based on this phenomenon to control the practice of money in politics there must be goodwill and commitment from all parties to strive to block the prohibited practice. Rules by including the spirit of credibility and accountability are not enough so that the moral aspects must be placed in the frontline. ${ }^{22}$

\footnotetext{
${ }^{20}$ Roy Mathen Moorti, Dampak Politik Uang Terhadap Domokrasi, Seminar Nasional Hukum, Universitas Negeri Semarang, Vol. 4 Nomor. 3 tahun 2018

${ }^{21}$ Results of Interview with Information on 5 July 2019

${ }^{22}$ Fatkuri, Politik Uang dan Uang Politik, https://news.detik.com/opini/d-1083642/politik-uangdan-uang-politik- diakses 10 November 2019
}

Tribakti: Jurnal Pemikiran Keislaman

Volume 31, Nomor 2, Juli 2020 
Besides the issue of money politics, hoaxes are a form of someone's inability to accept the conditions they face and try in any way to strengthen their dominance. The hoax created before this election in the aftermath of frustration, disappointment, and resistance to the actions of others who are considered detrimental to them. However, it is fitting that we must mutually support the implementation of this democratic party by not creating opinions that unsettle the public so that the election process can go well without any provocation. Elections are an opportunity for us to choose leaders who are ready to be able to build and advance this nation for the common good. Don't use hoaxes as a means of revenge or weapons to bring each other down, because that will only bury the hopes of the Indonesian people for the progress of this country.

\section{Eliminating qualified candidates}

Politics of money or one-way politics is very dangerous for the continuation of a democratic system. In addition to producing low-quality leaders, money politics also weakens democracy itself. The worst impact of money politics practices is that politicians are elected not without quality or integrity. As Sella said by students of SMAN 1 Kedungwaru, Tulungangung as follows:

"Money politics can eliminate the quality of candidates because people choose not based on the candidate's vision and mission in developing the area, but material, so that it can damage the candidate, because voters do not see the candidate's track record, whether good or not, but rather based on rewards material in the form of money or goods". ${ }^{23}$

The open proportional system mechanism in the 2019 election provides an opportunity for voters to make their choice, but if the recruitment of candidates that occurs only relies on material battles, then in political practice it will be very difficult to a void the emergence of political transactions in elections. This tendency can be proven in every election implementation, where political parties have started first by transacting to sit in the party management, continued in the determination of candidates, and to win the contest, candidates conduct political transactions with voters.

However, empirical evidence shows that some voters make their choice on candidates not based on the superiority of the program and ideology offered or the track record of the candidates, but rather on transactional politics. The money given by candidates through the successful team formed by the candidate becomes a magnet that

${ }^{23}$ Results of Interview with Information on 5 July 2019 
is so powerful in influencing the choice of prospective voters. This is caused not only by intense competition between prospective regional heads but also due to loss of trust between one another.

Indeed, quality leaders are born from a quality democratic process, namely democracy without money politics. one of them is by building elections with integrity. general elections should be used as political momentum to make changes, especially to punish candidates who do not keep their political promises, because the progress and failure of an area is influenced by a leader

\section{Influence voter participation}

A country that adopts a modern democratic system makes voter participation a measure of confidence in the success of the election process. Voter participation can also be interpreted by the involvement of voters in exercising their voting rights in the elections or elections. Voter participation itself is based on the Permanent Voter List (DPT) that has been determined through the KPU plenary meeting. As said by Muh Anam Rifai, the Head of Data and the Tulungagung Regency KPU program said:

"The number of Permanent Voter Lists in the 2019 Elections in Tulungagung Regency is 685,923 voters, while for the beginner voters as many as 11,519 voters, these beginner voters are aged 17-20 years and only cast their votes in the 2019 elections, most of the novice voters are from students". ${ }^{24}$

The sizeable number of new voters is certainly a magnet for candidates competing in the 2019 elections, within the norms of democratic standards, the political support provided by one actor to other the political actors is based on political equality of preference to fight for the interests of the public. However, through Money Politics, political support is provided for the consideration of other financial and economic resources that are received by certain political actors.

According to Jhon Karhoff, this condition is referred to as hybrid democracy, where the democratic mechanism takes place together with non-democratic practices, elections as one of the pillars of political democracy go hand in hand with the behavior of political money, hoaxes and Sara issues, which actually undermine democracy itself, even the rationality of voters becomes very questionable, voters do not choose candidates based on the program and vision offered but only based on the amount of money received before the election, in this case, according to Jhon Karkoff's theory, voter behavior is influenced

${ }^{24}$ Results of Interview with Informan in February 2019

Tribakti: Jurnal Pemikiran Keislaman

Volume 31, Nomor 2, Juli 2020 
by non-democratic factors so that the participant indicated in the use of the suffrage rate is more apparent.

\section{Conclusions}

Based on the results of the previous discussion, the conclusions of this study include; First, Students' perceptions of money politics, hoaxes, and sara issues at the 2019 general election in Tulungagung Regency as follows, the majority of students stated that money politics is the provision of cash and goods with the lure of promises to choose themselves to be categorized as money politics, it is in accordance with the definition of money politics according to the Act. While some students say money politics is cash distributed directly by candidates or the success team or promised to be given after voting. While most students understand hoaxes as hoax news or news that is unclear and inaccurate, there are also a small portion students consider hoaxes as a diversion of issues or news that corners the government, while students' understanding of Sara is views and actions based on identity sentiments concerning heredity, religion, nationality, or ethnicity and certain groups and there is a small part understanding Sara issues as actions involving violence, discrimination, and harassment based on self and group identity, what's interesting is that there are some students who think that Sara is a view not to choose a leader who is different from himself.

Second, factors that influence students' perceptions of money politics, hoaxes, Sara issues in the 2019 election are regulatory factors, this factor is key because in regulations regarding money politics and hoax news is very biased so that it can expand to various layers of society not except students in Tulungagung Regency, besides the candidate factor is also a cause, candidates who do not have political vision will usually use flawed methods such as money politics and hoaxes to bring down political opponents, the last is the capacity factor of the election organizer, this factor becomes very important because besides bringing down political opponents also attack the technicalities of the elections so organizers must respond quickly and decisively

Third, the implications of money politics, hoaxes, and Sara issues in influencing student choice in the 2019 elections in addition to damaging democracy also result in instability of the political system, giving birth to people's fears and worries, in addition to eliminating qualified candidates for money politics and hoaxes also have implications for the level of voter participation even though all. 


\section{References}

Abdu Salam, Politik, "Uang dan Pilkada”, Makalah 09 Juni 2010

Ammar Muhammad, Ferhadz, Menyikapi Isu Kecurangan Pemilu, Artikel yang dimuat dalam Detik.com pada tanggal 15 April 2019 dapat diakses melalui link https://news.detik.com/kolom/d-4511134/menyikapi-isu-kecurangan-pemilu

Anthony G. Wilhelm, Demokrasi di Era Digital : Tantangan Kehidupan Politik di Ruang Cyber (Yogyakarta: Pustaka Pelajar, 2003).

Burhanuddin Muhtadi, Politik Uang dan New Normal dalam Pemilu Paska Orde Baru, Jurnal Antikorupsi INTEGRITAS, 5 (1)

Fatkuri, Politik Uang dan Uang Politik, https://news.detik.com/opini/d-1083642/politikuang-dan-uang-politik- dikases tanggal 10 November 2019

Ibrahim Zuhdhy Fahmy, Uang dan Pilkada (Jakarta : Indonesia Corruption Watch, Januari 2010

"Infografis Hasil Survey MASTEL Tentang Wabah HOAX Nasional | Mastel.Id," MASTEL (blog), 13 Februari 2017, http://mastel.id/infografis-hasil-surveymastel-tentang-wabah-hoax-nasional/.

Ismawan, I. Money Politics Pengaruh Uang dalam Pemilu, Yogyakarta: Media Pressindo, 1999

Septiaji Nugroho, "Cara Cerdas Mencegah Penyebaran Hoax di Media Sosial," Kompas.com, $22 \quad$ November 2017, https://nasional.kompas.com/read/2017/11/22/08020091-cara-cerdas-mencegahpenyebaran-hoax-di-media-sosia.

Suharsimi Arikunto, Prosedur Penelitian: Suatu Pendekatan Praktek. Jakarta: PT. Rineka Cipta, 2002

Sugiyono. Metode Penelitian Administrasi. Bandung: CV. Alfabeta, 2004

Widjaya, Albert, Budaya Politik dan Pembangunan Ekonomi. Jakarta: LP3ES,1982 . 